\title{
Influence of Concrete Strength on the Cycle Performance of Composite Steel Plate Shear Walls
}

\author{
Amer M. Ibrahim, Huda M. Najem \\ Department of Civil Engineering, College of Engineering, University.of Diyala \\ huda.m.najem1992@gmail.com
}

\begin{abstract}
The goal behind this research is to highlight on structural system using composite steel plate shear wall, this approach is widely used in many countries, due to its desired features. Composite steel plate shear wall are often considered essential in design of building to resist seismic action. This paper discuss the effect of concrete strength on behavior of CSPW, for this objective one story one bay model with different compressive strength $(25$, $28,45,50,55,65) \mathrm{MPa}$, this model formed by finite element code which is advanced by university of Amirkabir. The accuracy of the representation of the model by numerical analysis, numerical result contrast with valid experiment which explain suitable agreement. Result show increasing the compressive strength would advance the cycle behavior. By contrast the result in elastic region, it was seen initial stiffness is not enhance by varying the compressive strength.
\end{abstract}

Keywords: Steel shear wall, Composite shear wall, Post buckling, Shear stud

Paper History: (Received: 19/9/2016; Accepted: 20/12/2016)

\section{Introduction}

Composite steel plate shear wall(CSPW) is lateral load resisting system used to resist lateral force represent by wind and earthquake. CSPW result from merging steel shear wall and concrete shear wall, in other meaning CSPW prevent buckling in steel plate and cracking in concrete wall. CSPW consist of infill steel plate and reinforced concrete wall on both side or one side of steel plate. The efficiency of behavior of CSPW depend upon connection between infill steel plate and concrete wall by shear stud or bolts. The massive advantage of CSPW is that prevent buckling from incidence in infill steel plate. One of the major benefits of CSPW is that uses to resist lateral load and used instead of steel structure. CSPW consider perfect choice for using in high rise building where large story shear load. It is worth mentioning that restricted study has been carried out on CSPW in which the reinforced concrete on one side. This range of research request more discuss, exceptionally numerical research are wanted to recognize the key parameters for cycle design. The basic function of concrete wall in modeled of CSPW is that to prevent early global and local elastic buckling of infill steel plate. Concrete wall strengthens the existing weaknesses in infill steel plate in compression field. The full pure shear yielding will appear, which is observation higher than diagonal tension field yield in steel shear wall.

In 1983, Timler and Kulak performed tests on steel shear walls without stiffening under monotonic and cyclic loadings. Their results showed good ductility and high lateral strength of this system. Within the limits of the tests, the absorbed energy was increased with deflection. If the S-shaped hysteresis loop is not satisfactory for the intended application, the plate will be stiffened. Utilizing the postbuckling strength of a SPSW system may result in a significant increase in cost.

In 2002, Astaneh-Asl study the ordinary steel and composite shear wall of two samples of three-story, at a scale of 1_3, under cyclic loads, have shown that the concrete layer produces a better distribution of stress in the steel plate, developing tension field lines in a wider region.

In 2002, Driver et al. conducted an experimental program to evaluate the ability of classical plate theory to predict the buckling of the face plates. Tests were performed on a series of web panels that simulate a portion of a girder web subjected to flexural compressive stresses. The experimentally determined buckling loads were used to validate the plate's theory. Two of the specimens were un-grouted, two were grouted with a cementation material, and one was grouted with an epoxy grout. It was confirmed that the presence of grout increases the buckling capacity of the face plates and the improved bond using epoxy grout served to delay buckling, although a 
sudden failure was recorded when the bond broke.

In 2003, De Matteis et al. schematized shear panels as equivalent bracing elements have a suitable hysteretic behavior. He concluded that low-yield steel shear panels provide considerable reduction in storey deflection and damage level of the primary structure.

In 2004, Zhao and Astaneh-Asl developed first model of smart composite steel plate shear wall which consist of infill steel plate, concrete wall on one side of steel plate and with gap between steel frame and concrete wall. Two half scale one bay three story models, with and without a gap, innovative and traditional, were inspect. An interest from adding gap to CSPW is that to reduce damage of concrete wall and enhance ductile mode.

In 2004, Bruneau and Bhagwagar conducted a nonlinear study to investigate how structural behavior is affected when a thin infill of steel, low-yield steel, or shear-fill fabrics are used. It was found that the use of even very thin steel infill panels can significantly reduce storey drifts without significant increases in floor accelerations, and that low-yield steel behaves somewhat better than standard constructional grade steel under extreme seismic conditions at the cost of additional materials.

In 2006, Alinia studied the effect of surrounding members on the overall behavior of thin steel plate shear walls. His results show that, the flexural stiffness of the surrounding members has no significant effect on elastic shear buckling or the post-buckling behavior of the shear walls.

In 2008, Rahai et al. developed smart CSPW and study effect distance between shear stud on behavior of smart CSPW and is it improved the performance or not. The result show that the increase distance between shear stud up to specific value enhance stiffness, ductility and energy dissipation.

In 2010, Arabzadeh et al. perform experimental model on one story and three story of CSPW with caliber of 1:4 and 1:3 respectively. Arabzadeh study effect number of shear stud on behavior of traditional CSPW and is it improve the performance or not. The result show that increasing the number of shear stud enhance strength and ductility of all system.

In 2011, Lanhui et al. developed one SPSW and one CSPW specimen with concrete filled circular steel tube columns. Lanhui want study the behavior of steel shear wall and composite steel shear wall and comparison between them. Both model were one bay two story with scale $1: 3$. The result show that the behavior of both system are roughly comparable but stiffness, ductility and energy dissipation of CSPW more effective than SPSW. CSPW are consider complex system so the need to more experimental and analytical studies. Proof of that does not have any study on the effect of concrete strength on cycle behavior of CSPW ,so in this paper by using finite element method four specimens of CSPW were modeled with gap $40 \mathrm{~mm}$ and concrete wall on one side of infill steel plate.

\section{Analytical Studied}

The numerical study of model made by finite element analysis by using (ANSYS) program version (13.0). The best size for the FE. Meshes were choice and the steel plate and shear wall frame were formed. Column and beam meshes were prepared so that they synchronize with the boundaries of the steel plate meshes so mutual joint would be modeled. Since the convergence criteria have been considered for force and displacement in all models. So the element choice to represent shear stud and reinforcement were a 3D link 180 element with 6 degree of freedom. The element used to represent infill steel plate ,beam and columns were 3D shell181 with 6 degree of freedom. The element used to represent concrete wall was 3D solid65. Interface surface between infill steel plate and concrete wall represent by targe170 and contact 174 . Finally load slip action represent by comb39. As shown in Figure 2.

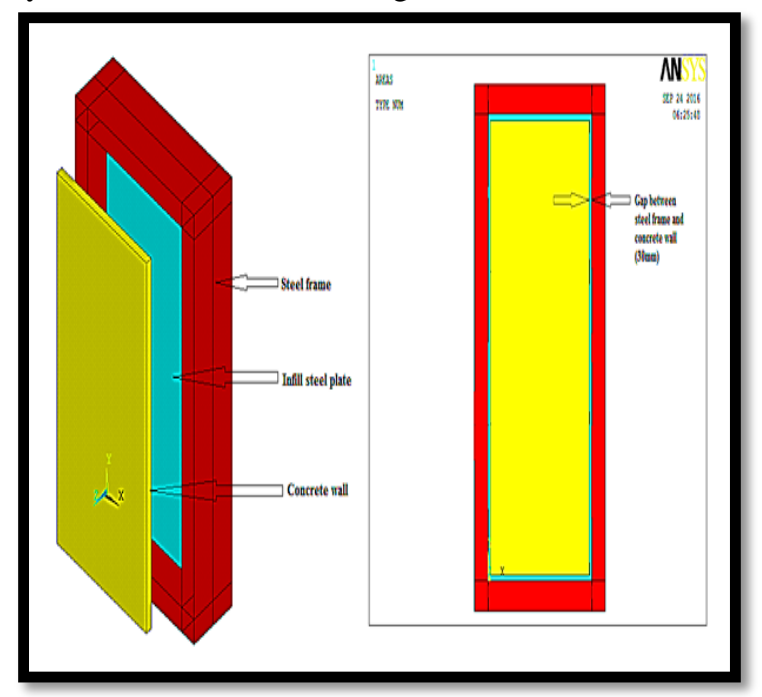

Figure 2: Composite steel plate shear wall(numerical )

\section{Description of Different Parts of the Composite Steel Plate Shear Wall System for its Performance}

Steel plate is a major element in composite shear wall. Preferably, this plate is chosen of steel with low yield point. For example St37 steel plate is preferred for high strength steel plate. Because St37 steel plate due to its low yield point is preferred to encourage yielding of steel plate. The reinforced concrete cover on one side or both sides of a steel plate carries 
some of the story shear by improve compression diagonal field and increased strength and stiffens. Of course major role of the reinforced concrete cover is to prevent out of plan buckling of steel plate prior to reaching yielding. Shear connectors are used to concrete is to block buckling of steel plate. In some case shear studs not only are subjected to shear but also to a considerable tension due to local buckling of the steel plate. For cast in place concrete, welded shear studs are usually utilized, for pre-cast concrete walls bolts can be used.

\section{Geometrical Properties of Models}

The length of frame span that is center distance to center of both sides column is $2000 \mathrm{~mm}$ and height is also frame $1000 \mathrm{~mm}$ which is center distance to center of top and bottom beams. Columns and beams sections were also double IPE2000 that were reinforced with two plates $(150 * 12)$ on the flanges. Steel plate inscribed inside the boundary beams and columns, it is $1776^{*} 776$ long and $1776^{*} 1776 \mathrm{~mm}$ wide, there is a $40 \mathrm{~mm}$ gap between the concrete cover and the boundary elements, $716 * 1716,1716 * 1716$ mm length and width In order to connect the concrete. Figure 1 show that Specimen dimensions.

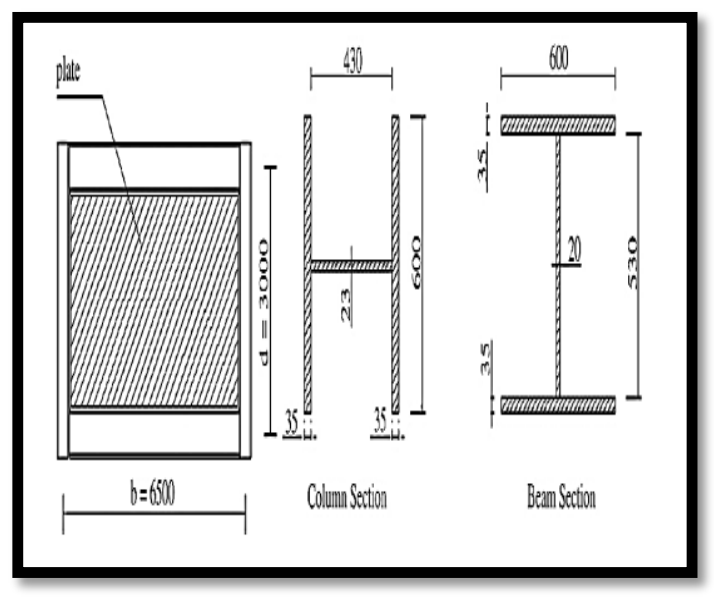

Figure 1: Specimen dimensions

\section{Modeling Theories}

To analyze model, the following theories were considered:

- Specimens at their lower level fixed on all directions.

- The behavior of used steel such as steel plate, beams, columns and bars inside the concrete considered bilinear. Meshing of models was also selected so that connecting the flange to web at columns and beams profile and steel plate to the boundary elements in specimens were rigid connections. Mesh dimensions was also maximum $40 * 40 \mathrm{~mm}$.

\section{Loading}

At loading the cyclic loading the rate of frequency is $1 / 60 \mathrm{HZ}$ and the rate of amplitude value of the force is $600 \mathrm{kN}$.As shown in Figure 3.

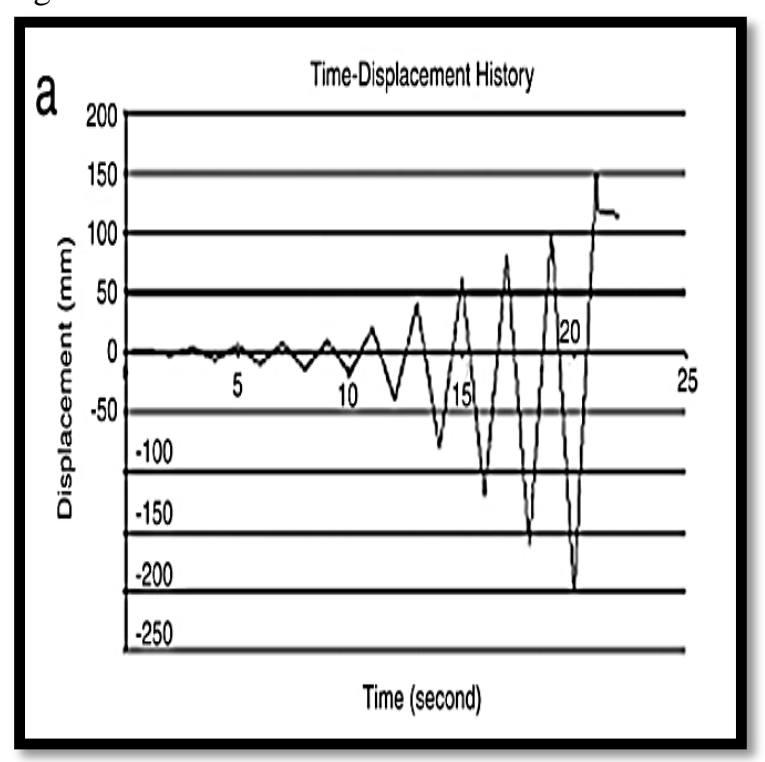

Figure 3: Cycle Loading

\section{Comparing the Result for the Numerical and Excremental Model}

To construct validity of analyzed model of composite shear wall specimen $(1000 * 2000$ $\mathrm{mm}$ ) on which the thickness of steel plate and concrete cover is 3 and $50 \mathrm{~mm}$ respectively, and height overall ratio to the span is $1 / 2$. Applied under cyclic loading and its deformation-load diagram drown and compared to the analyzed results of similar numerical model.

\section{Software Output Result in Cyclic Loading}

At the last cyclic loading step, at step 41 the results of ANSYS output presented in Figure 4 to see and compare out-of plane deflection of composite shear wall in different experimental and numerical specimens. 


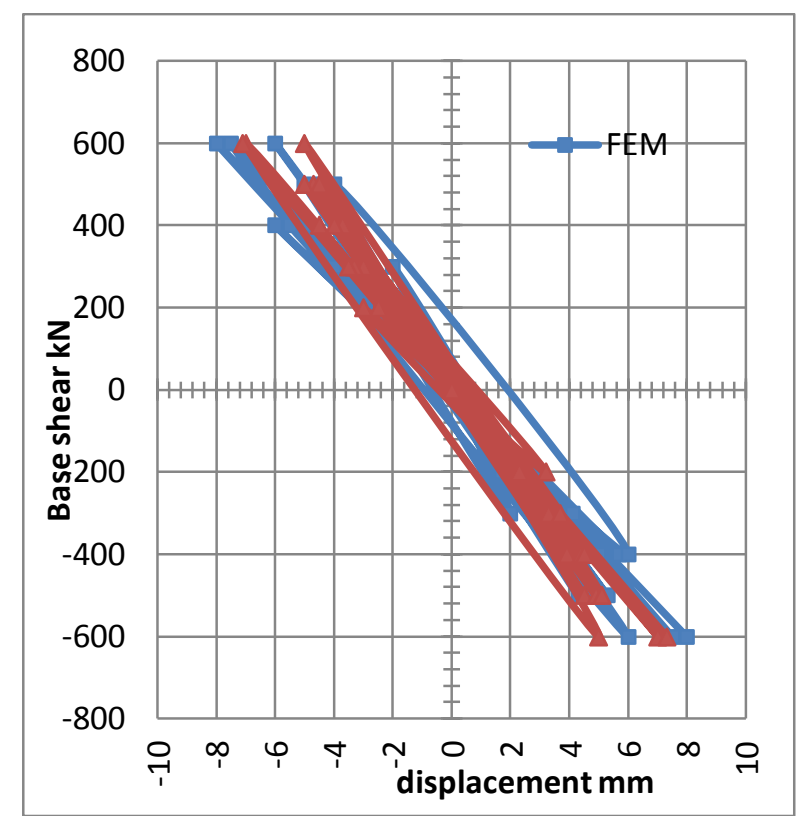

Figure 4: Comparing results of deformation-load in the numerical and experimental model for CSPW

9. Comparing the Result of Numerical Models Analysis

Changing the value of $\mathrm{F}_{\mathrm{c}}^{\prime}$ influences the material properties of concrete defined in the FE model in ANSYS in three different criteria as described previously in Chapter 3 namely, the initial modulus, the stress-strain relation and the smeared cracking model. In order to study the influence of $\mathrm{F}_{\mathrm{c}}^{\prime}$ on the cyclic performance of composite steel plate shear walls.

The FE model studies in this part consist off six different $\mathrm{F}_{\mathrm{c}}^{\prime}$ values. All the specimens modeled in this group has the following properties:

- $\quad$ Steel plate yield is $240 \mathrm{MPa}$.

- Reinforced at $1 \%$ of the concrete volume.

- $\quad$ Distance between shear stud was 200 $\mathrm{mm}$ and layout with $(3 * 8)$ (horizontal *vertical).

- $\quad$ Concrete panel thickness $50 \mathrm{~mm}$.

- Infill steel plate thickness was $3 \mathrm{~mm}$.

- $\quad$ (40 mm) gap between steel frame and concrete wall.

The first composite steel plate shear wall is the reference shear wall C.S.S.W.(GCS-40-50-3) with $\mathrm{F}_{\mathrm{c}}{ }_{\mathrm{c}}(25 \mathrm{MPa})$. The rest composite shear wall C.S.S.W.(GCS-40-50-3) with $\mathrm{F}_{\mathrm{c}} \quad(28$ $\mathrm{MPa})$, C.S.S.W.(GCS-40-50) with $\mathrm{F}_{\mathrm{c}} \quad(45$ $\mathrm{MPa})$, C.S.S.W.(GCS-40-50) with $\mathrm{F}_{\mathrm{c}}{ }_{\mathrm{c}}(50$ $\mathrm{MPa})$,C.S.S.W.(GCS-40-50) with $\mathrm{F}_{\mathrm{c}}{ }_{\mathrm{c}} \quad(55$ $\mathrm{MPa})$ and C.S.S.W.(GCS-40-50-3) with $\mathrm{F}^{\prime}{ }_{\mathrm{c}}$ (65 MPa). Fig. $(5,6,7,8,9,10)$ shown out off- plane deflection varying by changing the value of $\mathrm{F}_{\mathrm{c}}^{\prime}$.

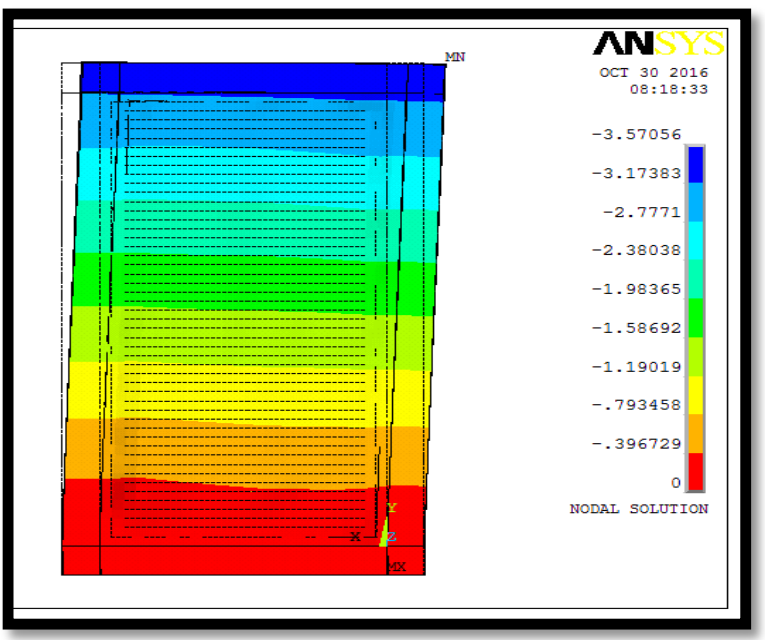

Figure 5: Out-of plane deflection of CSPW for $25 \mathrm{MPa}$

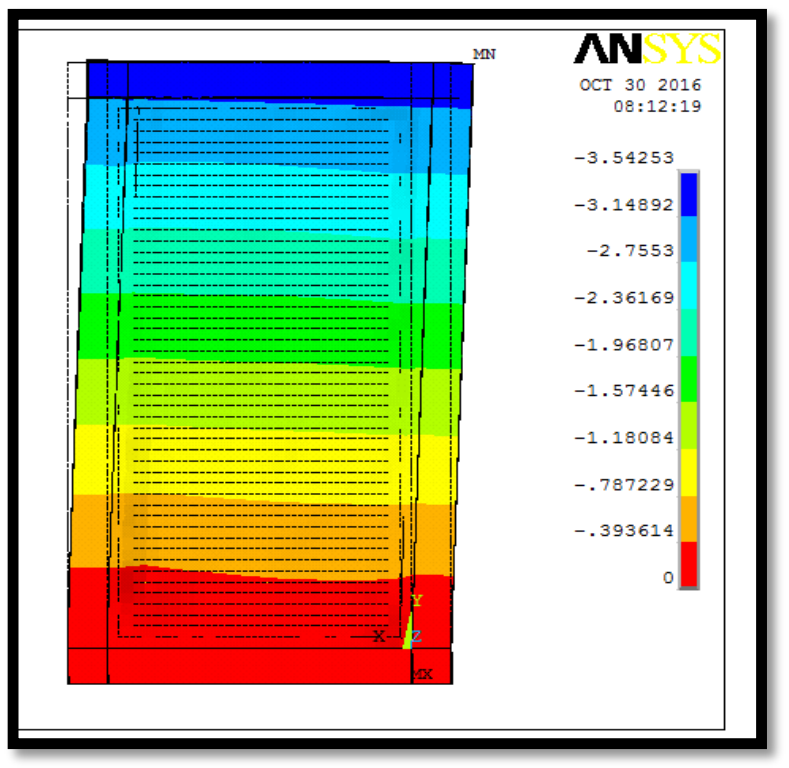

Figure 6: Out-of plane deflection of CSPW for $28 \mathrm{MPa}$

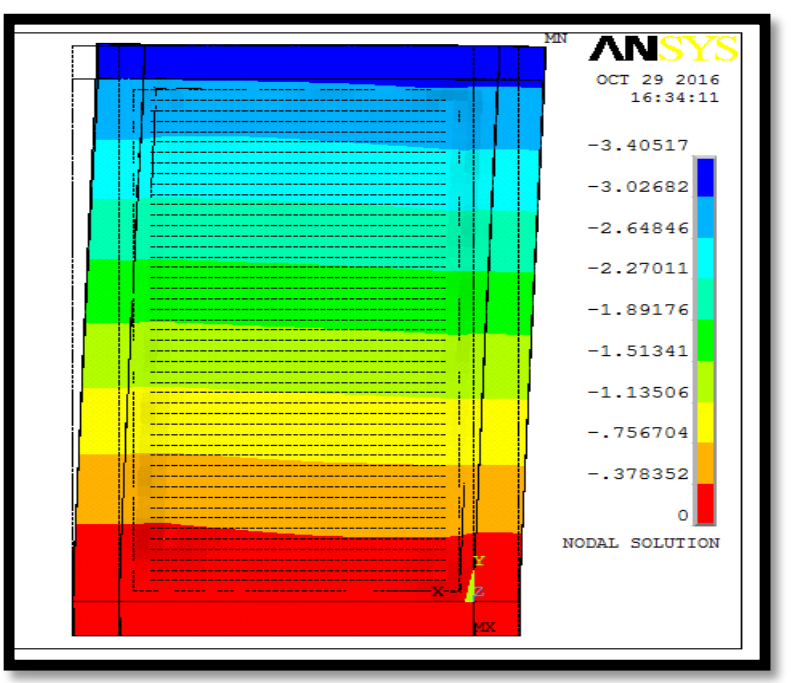

Figure 7: Out-of plane deflection of CSPW for $45 \mathrm{MPa}$ 


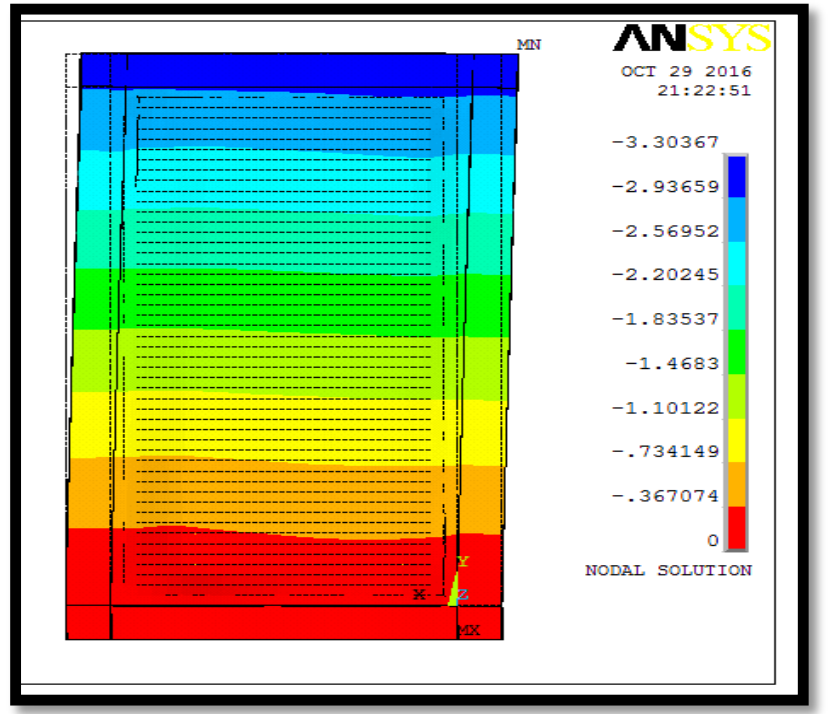

Figure 8: Out-of plane deflection of CSPW for $50 \mathrm{MPa}$

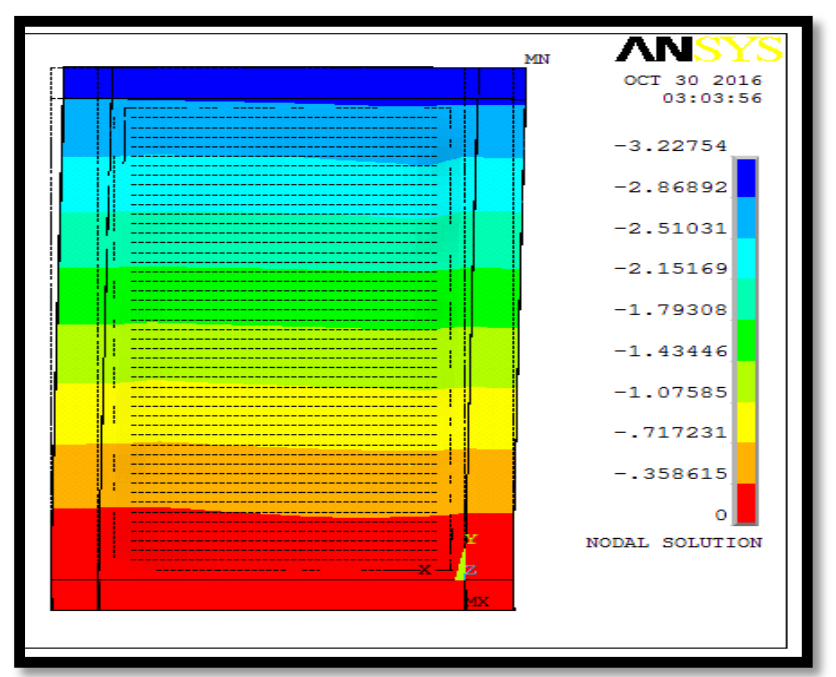

Figure 9: Out-of plane deflection of CSPW for $55 \mathrm{MPa}$

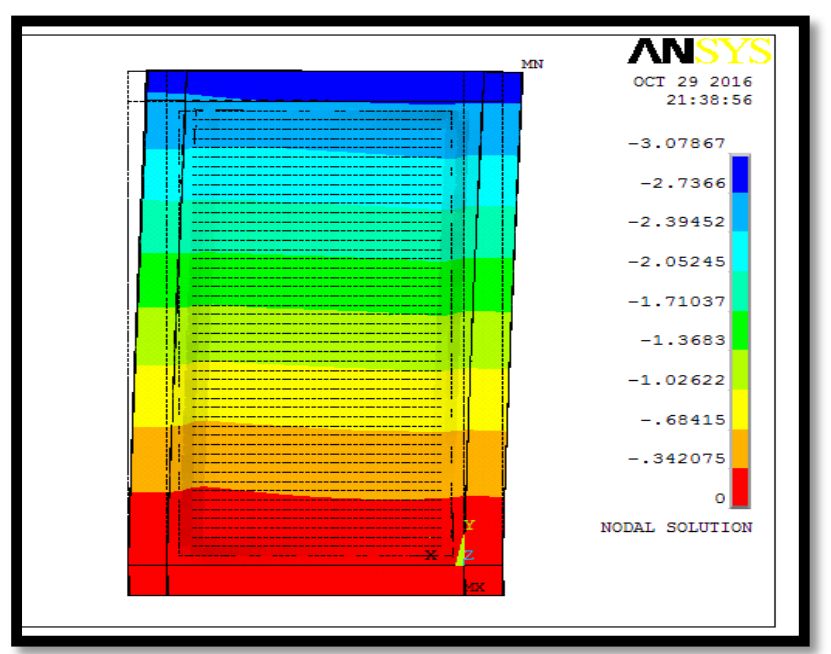

Figure 10: Out-of plane deflection of CSPW for 65 $\mathrm{MPa}$

\subsection{Initial Elastic Stiffness}

It is a measure of the specimen resistance to deformation and relates to how the specimen bends under the applied load. The specimen stiffness was calculated based on the ultimate load by tacking $100 \%$ of the ultimate load and displacement corresponding to this value of load. To find initial elastic stiffness, dividing max load on max deflection, also find the ratio of initial stiffness by dividing stiffness of specimen on the reference stiffness final stiffness and displacements involving the interaction between the composite plate and frame. Table 1 presents the initial elastic stiffness $(\mathrm{Ke})$ and ratios of the initial elastic stiffness $(\mathrm{Ke} / \mathrm{K})$

In accordance with Table 1, increasing the ratio of compressive strength from $(25) \mathrm{MPa}$ to $(28,45,50,55,65) \mathrm{MPa}$ enhances the initial lateral stiffness, the enhances are nearly( 2, 5, $8,10,14) \%$ for CSPSW.(GCS-40-50-3) with $F^{\prime}{ }_{c}(28,45,50,55,65) \mathrm{MPa}$. The main reason for increase stiffness when increase compressive strength is that, compressive strength enhance the properties of concrete wall and it is effect on the ability of shear wall to resist lateral load.

Table 1 Initial elastic stiffness of CSPW with different value of compressive strength.

\begin{tabular}{|c|c|c|c|c|}
\hline $\begin{array}{c}\text { Model } \\
\text { (specimen) }\end{array}$ & Load (kN) & $\begin{array}{l}\text { Lateral dis. } \\
\text { (mm) }\end{array}$ & $\begin{array}{c}K_{e}=F / D \\
(\mathrm{kN} / \mathrm{mm})\end{array}$ & $K_{e / K}$ \\
\hline $\begin{array}{c}\text { C.S.S.W. } \\
(\text { GCS-40-50-3) } \\
F_{c}^{\prime}=25 \mathrm{MPa}\end{array}$ & 600 & 3.57 & 168.07 & - \\
\hline $\begin{array}{c}\text { C.S.S.W. } \\
(\text { GCS-40-50-3) } \\
F_{c}^{\prime}=28 \mathrm{MPa}\end{array}$ & 600 & 3.51 & 170.94 & 1.02 \\
\hline $\begin{array}{c}\text { C.S.S.W. } \\
(\text { GCS-40-50-3) } \\
F_{c}^{\prime}=45 \text { MPa }\end{array}$ & 600 & 3.4 & 176.47 & 1.05 \\
\hline $\begin{array}{c}\text { C.S.S.W. } \\
(\text { GCS-40-50-3) } \\
F_{c}^{\prime}=50 \mathrm{MPa}\end{array}$ & 600 & 3.3 & 181.82 & 1.08 \\
\hline $\begin{array}{c}\text { C.S.S.W. } \\
(\text { GCS-40-50-3) } \\
F^{\prime}{ }_{c}=55 \mathrm{MPa}\end{array}$ & 600 & 3.22 & 186.34 & 1.11 \\
\hline $\begin{array}{c}\text { C.S.S.W. } \\
(\text { GCS }-40-50-3) \\
F^{\prime}{ }_{c}=65 \mathrm{MPa}\end{array}$ & 600 & 3.07 & 195.44 & 1.16 \\
\hline
\end{tabular}

\subsection{Ductility Ratios}

The ductility ratio is calculated as the ratio of the maximumpol displacement to the yield displacement $\left(\mu=\delta_{\max } / \delta_{y}\right)$. The yield point displacement $\left(\delta_{y}\right)$ is calculated through the concept of equal plastic energy, So that the area enclosed by the idealized elastic-plastic curve is equal to that of the actual push-over curve, as shown in Figure 11. CSPSW with different value of compressive strength have different ductility ratios. Table 2 depicts the calculated ductility of finite Element models and the ductility ratio of CSPSW(GCS-40-50$3)$ with $\mathrm{F}_{\mathrm{c}}^{\prime}(25 \mathrm{MPa})$ to CSPSW(GCS-40-50-3) with $\mathrm{F}_{\mathrm{c}}^{\prime}(28 \mathrm{MPa})$,CSPSW(GCS-40-50-3) with $\mathrm{F}_{\mathrm{c}}^{\prime}(45 \mathrm{MPa}), \quad \mathrm{CSPSW}(\mathrm{GCS}-40-50-3)$ with $\mathrm{F}_{\mathrm{c}}{ }_{\mathrm{c}}(50 \mathrm{MPa}), \quad \mathrm{CSPSW}(\mathrm{GCS}-40-50-3)$ 
with $\mathrm{F}_{\mathrm{c}}(55 \mathrm{MPa})$ and CSPSW(GCS-40-50-3) with $\mathrm{F}_{\mathrm{c}}{ }_{\mathrm{c}}(65 \mathrm{MPa})$. In accordance with Table 2, increasing the ratio of compressive strength from $(25) \mathrm{MPa}$ to $(28,45,50,55,65) \mathrm{MPa}$ enhances the ductility ratio, the enhances are nearly( 3, 27, 33, 41, 47)\% for CSPSW.(GCS40-50-3) with $F^{\prime}{ }_{c}(28,45,50,55,65) \mathrm{MPa}$. The main reason for increase ductility when increase compressive strength is that, deflection of all model decrease when compressive strength increased and it is effect on the ability of shear wall to resist lateral load.

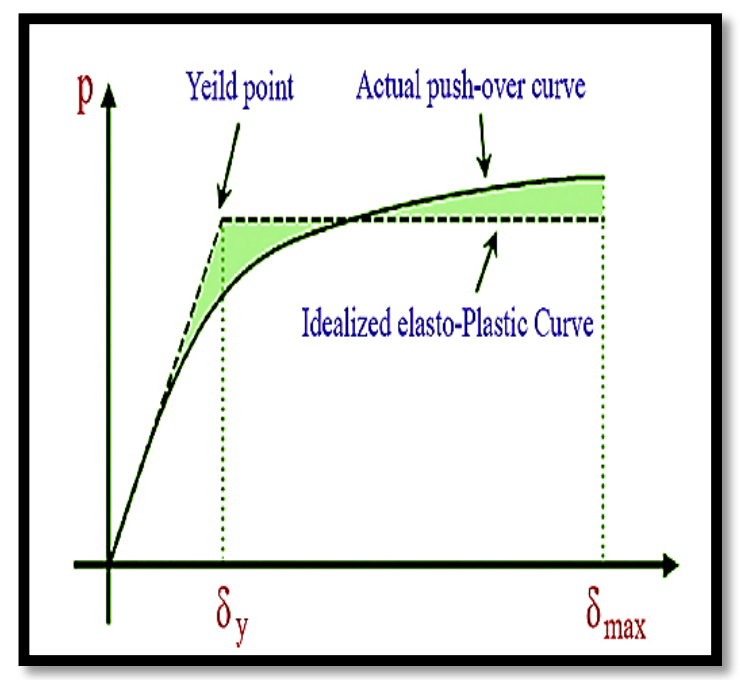

Figure 11: Definition Of A Yield Point

Table 2 Ductility ratio of CSPWS with different value of compressive strength.

\begin{tabular}{|c|c|c|c|c|}
\hline $\begin{array}{c}\text { Model } \\
\text { (specimen) }\end{array}$ & $\begin{array}{l}\delta_{\max } \\
(\mathrm{mm})\end{array}$ & $\begin{array}{c}\delta_{y} \\
(\mathrm{~mm})\end{array}$ & $\mu=\delta_{\max } / \delta_{y}$ & $\mu_{e} / \mu$ \\
\hline $\begin{array}{c}\text { C.S.S.W. } \\
(\text { GCS-40-50-3) } \\
F_{c}^{\prime}=25 \mathrm{MPa}\end{array}$ & 3.57 & 1.89 & 1.89 & - \\
\hline $\begin{array}{r}\text { C.S.S.W. } \\
(\text { GCS-40-50-3) } \\
F_{c}^{\prime}=28 \mathrm{MPa}\end{array}$ & 3.51 & 1.82 & 1.95 & 1.03 \\
\hline $\begin{array}{c}\text { C.S.S.W. } \\
(\text { GCS-40-50-3) } \\
F_{c}^{\prime}=45 \mathrm{MPa}\end{array}$ & 3.4 & 1.3 & 2.62 & 1.39 \\
\hline $\begin{array}{r}\text { C.S.S.W. } \\
(\text { GCS-40-50-3) } \\
F_{c}^{\prime}=50 \mathrm{MPa}\end{array}$ & 3.3 & 1.17 & 2.82 & 1.49 \\
\hline $\begin{array}{c}\text { C.S.S.W. } \\
(\text { GCS-40-50-3) } \\
F_{c}^{\prime}=55 \mathrm{MPa}\end{array}$ & 3.22 & 1 & 3.22 & 1.70 \\
\hline $\begin{array}{c}\text { C.S.S.W. } \\
(\text { GCS-40-50-3) } \\
F_{c}^{\prime}=65 \mathrm{MPa}\end{array}$ & 3.07 & 0.87 & 3.57 & 1.89 \\
\hline
\end{tabular}

\subsection{Energy Absorption}

Energy absorption capability is an important indicator of model's tolerance to loading. Models with high energy absorption capability are usually found to have high resistance to impact and crash loading, and hence are useful for high performance structures. The absorbed energy by a shear wall in a half-cycle can be rationally assumed as the area under(shear load-displacement), from which the area of recoverable elastic is not subtracted. It is presumed that the unloading and the elastic moduli are approximately the same. depicts the calculated absorbed energy and the percentage of improvement in energy absorption in CSPSW(GCS-40-50-3) with $\mathrm{F}_{\mathrm{c}}{ }_{\mathrm{c}}(25 \mathrm{MPa})$. as compared to their corresponding to CSPSW(GCS-40-50-3) wit F ${ }_{c}(28 \mathrm{MPa})$, CSPSW(GCS-40-50-3) with $\mathrm{F}_{{ }^{\prime}}(45 \mathrm{MPa})$, CSPSW(GCS-40-50-3) with $\mathrm{F}_{\mathrm{c}}{ }_{\mathrm{c}}(50 \mathrm{MPa})$, CSPSW(GCS-40-50-3) with $\mathrm{F}_{\mathrm{c}}^{\prime}(55 \mathrm{MPa})$ and CSPSW(GCS-40-50-3) with $\mathrm{F}_{\mathrm{c}}{ }_{\mathrm{c}}(65$ $\mathrm{MPa}$ ). In accordance to the Table (3), the energy absorption of CSPSW(GCS-40-50-3) with $\mathrm{F}_{\mathrm{c}}{ }_{\mathrm{c}}(28 \mathrm{MPa})$ are improved, as the value of compressive strength decreases. In accordance with Table 3 , increasing the ratio of compressive strength from (25) MPa to (28, $45,50,55,65) \mathrm{MPa}$ discouraged the energy absorption, the damping are nearly $(2,5,8,11$, 16)\% for CSPSW.(GCS-40-50-3) with $F_{c}{ }_{c}(28,45,50,55,65) \mathrm{MPa}$.

Table 3 Energy absorption of CSPWS with different value of compressive strength.

\begin{tabular}{|c|c|c|}
\hline $\begin{array}{c}\text { Model } \\
\text { (specimen) }\end{array}$ & $\begin{array}{l}\text { Energy absorption } \\
\text { (KJ) }\end{array}$ & $\begin{array}{c}\text { Energy absorption } \\
\text { ratio } \%\end{array}$ \\
\hline $\begin{array}{c}\text { C.S.S.W. } \\
(\text { GCS-40-50-3) } \\
F_{c}^{\prime}=25 \mathrm{MPa}\end{array}$ & 714 & - \\
\hline $\begin{array}{c}\text { C.S.S.W. } \\
(\text { GCS-40-50-3) } \\
F^{\prime}=28 \mathrm{MPa}\end{array}$ & 702 & 0.98 \\
\hline $\begin{array}{c}\text { C.S.S.W. } \\
\text { (GCS-40-50-3) } \\
F_{c}^{\prime}=45 \mathrm{MPa}\end{array}$ & 680 & 0.95 \\
\hline $\begin{array}{c}\text { C.S.S.W. } \\
(\text { GCS-40-50-3) } \\
F_{c}^{\prime}=50 \mathrm{MPa}\end{array}$ & 660 & 0.92 \\
\hline $\begin{array}{l}\text { C.S.S.W. } \\
(\text { GCS-40-50-3) } \\
F_{c}^{\prime}=55 \mathrm{MPa}\end{array}$ & 644 & 0.90 \\
\hline $\begin{array}{c}\text { C.S.S.W. } \\
(\mathrm{GCS}-40-50-3) \\
F_{S}^{\prime}=65 \mathrm{MPa}\end{array}$ & 614 & 0.86 \\
\hline
\end{tabular}

\section{Summary and Conclusion}

Variations in the value of compressive strength of concrete wall can increase stiffness and ductility. With respect to the analysis, max ratio of enhance for stiffness and ductility obtained for composite steel plate shear wall as $1: 3$ scales equivalent $14 \%, 47 \%$ with respect to compressive strength $(65 \mathrm{MPa})$ of concrete wall, in other meaning when compressive strength is large, the CSPW exhibits plump hysteretic curve under cyclic loading, meaning better behavior of all model.

\section{References}

[1]. Alinia, M. M., \& Dastfan, M., Behaviour of thin steel plate shear walls regarding frame members. Journal of constructional steel research, 62(7), (2006), 730-738.

[2]. Arabzade, A., Moharami, H., \& Ayazi, A., Local elastic buckling coefficients of steel 
plates in composite steel plate shear walls. Scientia Iranica, 18(1), (2011), 915.

[3]. Astaneh-Asl, A., Seismic behavior and design of composite steel plate shear walls. USA: Structural Steel Educational Council, 2002.

[4]. Astaneh-Asl, A., \& Zhao, Q., Seismic studies of an innovative and traditional composite shear walls. Composite and Hybrid Structures. Los Angeles, California: Association for International Cooperation and Research in SteelConcrete Composite Structures, 1009-16, 2000.

[5]. Berman, J. W., \& Bruneau, M., Steel Plate Shear Walls Are Not Plate Girders. Engineering Journal-American Institute Of Steel Construction, 41, (2004), 95-106.

[6]. De Matteis, G., Landolfo, R., \& Mazzolani, F. M., Seismic response of MR steel frames with low-yield steel shear panels. Engineering Structures, 25(2), (2003), 155-168.

[7]. Driver, R. G., Abbas, H. H., \& Sause, R., Local buckling of grouted and ungrouted internally stiffened double-plate HPS webs. Journal of Constructional Steel Research, 58(5), (2002), 881-906.

[8]. Driver, R. G., Kulak, G. L., Kennedy, D. L., \& Elwi, A. E., Cyclic test of four-story steel plate shear wall. Journal of Structural Engineering, 124(2), (1998), 112-120.

[9]. Guo, L., Li, R., Rong, Q., \& Zhang, S., Cyclic behavior of SPSW and CSPSW in composite frame. Thin-Walled Structures, 51, (20120, 39-52.

[10]. Guo, L., Ma, X., Li, R., \& Zhang, S., Experimental research on the seismic behavior of CSPSW connected to frame beams. Earthquake Engineering and
Engineering Vibration, 10(1), (2011), 6573.

[11]. Kulak, G. L. Unstiffened steel plate shear walls. Elsevier Applied Science Publishers, New York, NY, 1991.

[12]. Rahai, A. R., \& Alipoura, M., Behavior and characteristics of innovative composite plate shear walls. Procedia Engineering, 14, (2011), 3205-3212.

[13]. Rahai, A., \& Hatami, F., Evaluation of composite shear wall behavior under cyclic loadings. Journal of constructional steel research, 65(7), (2009), 1528-1537.

[14]. Rassouli, B., Shafaei, S., Ayazi, A., \& Farahbod, F., Experimental and numerical study on steel-concrete composite shear wall using light-weight concrete. Journal of Constructional Steel Research, 126, (2016), 117-128.

[15]. Tavárez, F. A., Simulation of behavior of composite grid reinforced concrete beams using explicit finite element methods. University of Wisconsin-Madison, 2001.

[16]. Timler, P. A., \& Kulak, G. L., Experimental study of steel plate shear walls, (1983).

[17]. Zhao, Q., \& Astaneh-Asl, A., Cyclic behavior of traditional and innovative composite shear walls. Journal of Structural Engineering, 130(2), (2004), 271-284.

[18]. Zhou, J., Mo, Y. L., Sun, X., \& Li, J., Seismic performance of composite steel plate reinforced concrete shear wall. In ASCE Conference Earth and Space 2010: Engineering, Science, Construction, and Operations in Challenging Environments, (2010), 3002-3010. 